\title{
Using Metaphors in Restoring Nature
}

\author{
Jozef Keulartz
}

\begin{abstract}
There has recently been growing interest in the role of metaphors in environmentalism and nature conservation. Metaphors not only structure how we perceive and think but also how we should act. The metaphor of nature as a book provokes a different attitude and kind of nature management than the metaphor of nature as a machine, an organism, or a network. This article explores four clusters of metaphors that are frequently used in framing ecological restoration: metaphors from the domains of engineering and cybernetics; art and aesthetics; medicine and health care; and geography. The article argues that these metaphors, like all metaphors, are restricted in range and relevance, and that we should adopt a multiple vision on metaphor. The adoption and development of such a multiple vision will facilitate communication and cooperation across the boundaries that separate different kinds of nature management and groups of experts and other stakeholders.
\end{abstract}

\section{KEYWORDS}

metaphor, environmental engineering, ecological restoration, ecosystem health, ecological network, functionalism, compositionalism

\section{Introduction}

Since George Lakoff and Mark Johnson's Metaphors We Live By (1980), metaphors are no longer seen as merely superficial and superfluous linguistic ornaments, but are considered as indispensable conceptual tools in thinking, talking, and acting.

Metaphors perform important cognitive functions, operating as mechanisms for the translation of something abstract into something concrete and shedding light on new and unknown phenomena through familiar ones. In short, metaphors are heuristic devices crucial for creating and conceptualizing novel ideas and new knowledge.

However, metaphors are not only important cognitive tools in making sense of the world but also important discursive tools that enable communication and negotiation with others throughout the world. Metaphors then are also diplomatic devices that facilitate interaction between different disciplines and discourses (Hellsten 2002). 
Moreover, metaphors also have a clear normative function. They not only determine our thinking and talking, but also our acting. As Donald Schön has stressed, metaphors enable us - mostly automatically and unconsciously_to make a "normative leap" from data to recommendations, from facts to values, from "is" to "ought." Schön (1979) gives the example of a slum that could either be framed as a "blight" (to be excised), or as a "natural community" threatened with destruction (calling for enhancement as a vehicle for social learning). Once we have framed problematic situations in terms of a normative dualism, such as health/disease or nature/artifice, we know what direction to move in.

Taken together, the cognitive, discursive, and normative functions of metaphors determine our attitude towards entities in the world. Thus, for example, people who see nature as a divine text will be more likely to adopt a passive rather than an active attitude towards nature, while those who look at nature as a machine might stress our possibilities to control, command, and correct nature.

Once it is acknowledged that the use of metaphor is inescapable and indispensable, however, we are confronted with the problem of the sheer multiplicity of metaphors. With respect to nature, Daniel J. Philippon (2004) has provided us with an extensive, although not exhaustive, list of metaphors for nature. Nature can be compared to a particular place (frontier, garden, park, wilderness, utopia), to a friend or family member (self, mother, father, sister, brother, wife, husband, partner), an actor (god or goddess, minister, monarch, lawyer, selective breeder, enemy), a network (web, community, tapestry), a machine (clock, engine, computer, spaceship), a state of being (virgin, harmony, balance), a mode of communication (book), a built object (bank, sink, storehouse, pharmacy, lifeboat, home), or to a contested landscape (battlefield, commons) (Philippon 2004: 16; see also Harré et al. 1999).

Confronted with this diversity and heterogeneity of metaphors for nature, many environmental philosophers and environmental activists still react with the attempt to reduce this multiplicity and search for the one best metaphor for nature (Ebenreck 1996; Mills 1982). But recently there is a growing awareness that one simply has to accept the plurality of metaphors.

In this article I want to defend this pluralism as a normative value in itself by examining and comparing the most important metaphors that are used in framing ecological restoration and explore their cognitive, discursive, and normative possibilities as well as their limits. ${ }^{1}$ I will deal successively with metaphors originating from the domains of engineering and cybernetics, of art and aesthetics, of medicine and 
health care, and of geography. I will then argue that we should not look for the best metaphor but that we should develop a multiple vision on metaphors. I will conclude with some preliminary answers to the question of how we should conceptualize the relation between the various metaphors used in restoring nature.

\section{Engineering and Cybernetics}

Activities to repair environmental damage were initiated by environmental engineering, a discipline that evolved in the early 1970s from sanitary engineering when various fields such as biochemistry, microbiology, fluid mechanics, physical and chemical oceanography, and meteorology were integrated into traditional courses on drinking water, wastewater, water quality, and air pollution (McCutcheon and Mitsch 1994). The emerging discipline of environmental engineering had its own journal, The Journal of Environmental Engineering, published by the American Society of Civil Engineers.

By the late 1980s a new discipline appeared on the environmental scene: ecological engineering. The ecological engineers launched their own journal in 1992, Ecological Engineering, The Journal of Ecotechnology. Ecological engineers or "ecotechnologists" filled niches left vacant by environmental engineers and gained a foothold especially in the areas of wetlands creation and ecosystem restoration (McCutcheon and Walski 1994). Mainly based on the work of Howard Odum, who was named as honorary editor of Ecological Engineering on the occasion of his 70th birthday, ecological engineering was defined as "the design of human society with its natural environment for the benefit of both" (Mitsch 1994). Ecological engineering is an important offshoot of the New Ecology, a new approach within the field of conservation biology that can be traced back to cybernetics, which flourished in the United States in the early post-World War II years in a climate of technocratic optimism. The politicians, having proved unable to cope with the problems of a complex industrial society, were urged to make way for social engineers who would then manage society as a self-regulating machine. One of these technocrats, Evelyn Hutchinson, was to leave an indelible mark on post-war ecology, particularly through the work of Howard Odum and his brother Eugene (Taylor 1988).

Cybernetics has displayed extraordinary communicative power because it is compatible with two comprehensive root metaphors that 
have shaped belief systems or "world hypotheses" with a long history in Western tradition: organicism and mechanism (Pepper 1942). This compatibility can be clearly observed in the work of Norbert Wiener, the founder of cybernetics. When he first coined the word "cybernetics" in 1945, he defined it as "control and communication in the animal and the machine." Wiener brought together two fields of research. On the one hand, he elaborated on the engineering-oriented research into the "servomechanical" nature of control and communication in machines, using the ideas of information flow, noise, feedback, and stability. On the other hand, he built on what physiologists like Walter Canon had developed under the headings of "homeostasis": a variety of mechanisms in the organism to maintain fixed levels of blood sugar, blood proteins, fat, and calcium as well as an adequate supply of oxygen, a constant body temperature, and so on. Whereas Wiener sought to extend his cybernetic program to social systems, Hutchinson and his students, Howard and Eugene Odum, applied this program to ecosystems, stressing their tendency to maintain or restore homeostasis through self-regulating feedback mechanisms.

Because the cybernetic concept of ecosystems is consistent both with organic and mechanic worldviews, it could fulfill an intermediary role between ecologists and politicians during the preparatory years of the International Biological Programme (1963-1968), which coincided with a general wave in environmental consciousness (Kwa 1987). The concept also appealed to both technocrats and environmentalists. To technocrats, it offered an image of a closed system that could be controlled and manipulated from a position outside or superior to the system and so gave rise to an immense technological optimism. On the other hand, the cybernetic concept allowed environmentalists to consider and admire ecosystems as large interdependent wholes that are definitely more than the sum of their parts.

However, from the early 1970s onward, the cybernetic concept of ecosystems as intermediary started to disintegrate and lose its attractiveness for environmentalists. At first glance, the concept's holism seemed to counteract the reductionist implications of the mechanistic and materialistic metaphors of nature that emerged during the scientific revolution of the seventeenth century and that were held responsible for the decline in community spirit and the alienation from nature (Bergson 1907; Merchant 1980; Whitehead 1925). However, on further consideration, environmentalists became convinced that the cybernetic metaphors seemed to be little more than sophisticated versions of the 
same old mechanistic metaphors (Meisner 1995). In fact, as some have argued, systems ecology does not proceed in a less reductionist fashion than classic natural sciences, but its reductionism is of a totally different order. Reductionism in classic natural sciences refers to a reduction in elements, such as atoms or molecules, that are identical in a material sense. Systems ecology, on the other hand, is concerned with components that are identical in a functional sense because they perform the same function within the ecosystem, for example, that of producers, consumers, or decomposers (bacteria and fungi). Such reductionism allows for a trade-off between organisms with a similar function with the aim of optimising the biomass yield (Keulartz 1998: 149).

The terminology of "producers," "consumers," and "biomass yield" brings to light another domain of metaphors that is important in shaping the outlook of the New Ecology: modern economy. As Donald Worster (1977) has shown, exponents of the New Ecology view nature as a set of resources with cash value; they have transformed nature into a reflection of the modern corporate state, a chain of factories, and an assembly line.

The mechanistic and economic metaphors of nature share a pronounced anthropocentric character. Many environmentalists are deeply concerned about the destructive consequences of such an anthropocentrism. Whenever man sets himself up as the measure of all things, so runs the environmentalist critique of anthropocentrism, nature, including human nature, ceases to be an independent and inexhaustible source of value. It becomes instead a mere resource to be disposed of at will, with all the detrimental consequences for the environment. If we are to prevent the environmental crisis from ending in catastrophe, environmental philosophers agree, we must convert to nonanthropocentrism, judging life forms on their intrinsic value and not on their instrumental value.

Following the famous philosopher Martin Heidegger, many environmentalists are convinced that we should no longer approach nature in terms of its utility and availability to our insatiable will to power but instead adopt an attitude of responsiveness and "releasement" (Gelassenheit). Man should learn to behave more like a shepherd than as a lord of being. We will get nearer to such an attitude if we turn to another source of metaphors, the field of art and aesthetics, which has inspired the theory and practice of ecological restoration, at least in its formative stages. 


\section{Art and Aesthetics}

In 1981 William R. Jordan III, who coined the term "ecological restoration," founded the oldest journal that deals exclusively with the subject of restoring ecosystems, first as Restoration \& Management Notes and from 1999 as Ecological Restoration. Jordan is also a founding member of the Society for Ecological Restoration International (SER) that was established in 1988. In 1993 SER published the first issue of its flagship journal, Restoration Ecology.

Ecological restoration is considered an intentional activity that initiates or accelerates the return of an ecosystem to its historical origin. Ecological restoration differs from ecological engineering with respect to the predictability of outcomes. "Predictability is a primary consideration in all engineering design, whereas restoration recognizes and accepts unpredictable development and addresses goals that reach beyond strict pragmatism and encompass biodiversity and ecosystem integrity and health" (Society for Ecological Restoration Science and Policy Working Group 2004: 12).

Because restoration attempts to return an ecosystem to its historic trajectory, historic conditions are the ideal starting point for restoration design. Although it may be difficult or impossible to determine the historic trajectory of a severely impacted ecosystem with accuracy, the general direction and boundaries of that trajectory can, nevertheless, be established through knowledge of the damaged ecosystem's preexisting structure, composition and functioning (palaeo-references), and through studies on comparable intact ecosystems elsewhere (actuoreferences).

From the outset, ecological restoration's attempt to return degraded ecosystems to their original state has been interpreted in terms of the restoration of artworks. This metaphor was put forward by environmental philosophers in particular (Gobster and Hull 2000; Throop 2000). At first, the comparison of nature to art was made in order to discredit ecological restoration. In his famous 1982 paper Faking Nature, Australian philosopher Robert Elliot argued that ecological restoration is akin to art forgery. Just as a reproduction or a replicate cannot reproduce the value of an original artwork, restored nature cannot reproduce the value of original nature. "What the environmental engineers are proposing is that we accept a fake or forgery instead of the real thing" (Eliot 2003: 383). A Van Meegeren will, of course, always be inferior to a real Vermeer! 
In his 1992 paper "The Big Lie: Human Restoration of Nature," environmental philosopher Eric Katz further argued that whatever is produced in a restored landscape certainly cannot count as having the original value of nature, particularly wild nature, and that restored nature necessarily represents a form of disvalue and domination of nature. "Once we dominate nature, once we restore and redesign nature for our own purposes, then we have destroyed nature-we have created an artifactual reality, in a sense, a false reality, which merely provides us the pleasant illusory appearance of the natural environment" (Katz 2003: 396).

Other environmental philosophers are less harsh in their judgement of restored nature. Andrew Light (2003), for instance, thinks that Eliot's and Katz's criticisms are only valid with respect to a particularly malicious kind of restoration-restoration that is used to justify the disturbance or destruction of nature, for instance for the benefit of some industrial activity, with the argument that it is possible nowadays to create a piece of nature with the same value as the original at a later date or at a different place. But, Light insists, this kind of restoration is relatively rare. Most restoration efforts are undertaken to correct a past harm. In these cases, ecological restoration is more akin to art restoration than to art reproduction or art forgery.

However, this metaphor is not entirely unproblematic because the very idea of restoration of artworks is itself controversial, as Light points out with reference to the early aesthetic theory of Mark Sagoff. In 1978, before he ever turned to environmental questions, Sagoff published an article, "On Restoring and Reproducing Art," in which he argued that not just any art restoration should count as a legitimate restoration. Here, Sagoff draws a distinction between integral and purist art restorations. An integral restoration puts new pieces in the place of original fragments that have been lost. The point of integral restoration is to make the whole work look original. Sagoff rejects this kind of restoration as both aesthetically and ethically troublesome, and he is obviously in favor of purist restorations. "A purist restoration limits itself to cleaning works of art and to reattaching original pieces that may have fallen. Purists contend that nothing inauthentic-nothing not produced by the original artist-may be shown" (Sagoff 1978: 457). A purist restoration allows viewers to imagine a work of art as complete, yet, at the same time, to see what is authentic and what is not, whereas an integral restoration only succeeds if viewers cannot tell the difference between the original and the restored work. Integral restora- 
tions not only diminish or even destroy the original value of an artwork, purists argue, they also deceive the public.

Following Sagoff, Light claims that any integral restoration of nature, even if it is benevolent, cannot have the same value as original nature. He seems to be somewhat less rigorous than Sagoff, however, in assuming that one can distinguish between different kinds of integral ecological restorations as better or worse. But, more importantly, Light claims that many ecological restorations amount to something more akin to purist than to integral restorations. Light mentions cleanups as the most obvious cases of purist restoration. Clean-ups include the bio-activation of existing micro-organisms in soils to allow the land to essentially clean itself up, and cleaning out exotic plants that were introduced at some time into a site, allowing the native plants to reestablish themselves.

However, the purist view on ecological restoration is more problematic than Light seems willing to acknowledge. Purists respect a work of art as the result of a particular process, as the creation of a particular artist working at a certain place and time, and not merely as a bearer of aesthetic properties. Here, however, the art-nature analogy may ultimately break down. Even if we would allow the existence of a master craftsman to whom we may attribute the authorship of nature, his or her products can never be traced back to a particular place and time. Among ecologists and conservationists there is an ongoing discussion about the question of which historical reference one should choose. Should one go back to the last interglacial era when humankind did not even yet have projectile weapons such as the bow and arrow and therefore was not yet capable of submitting his natural enemies? Should one go back to the time before the emergence of agriculture, or should one only have to go back to pre-industrial times and resort to traditional agrarian techniques such as reed and brushwood cultivation, tree planting and felling, and mowing and turf cutting?

The answer to this question depends on how one considers the relationship between humans and nature. This relationship can only be compared, in a severely limited way, to our aesthetic attitude towards works of art. This attitude is one of sympathetic contemplation of an object for its own sake. According to the eighteenth-century philosopher Immanuel Kant, works of art possess a certain "Zweckmässigkeit ohne Zweck" (purposiveness without a purpose). He describes the way we experience their beauty as "interesseloses Wohlgefallen" (disinterested pleasure). However, nature is never solely the object of experiences of beauty or the sublime but has many other functions. Water, 
for instance, is important to traffic, transportation, food supply, irrigation, recreation, and domestic use.

Another major difference between art and nature, as Rolston (2000) has argued, is that works of art are entirely passive and, left to themselves, decay inevitably. We restore them; they do not restore themselves. In contrast, left to itself nature flourishes and can restore itself. However, this argument is only valid as long as we stay focused on the visual arts. If we turn to performing arts like theatre, dance, or music, the restoration metaphor acquires a different meaning. A ballet, symphony, or play is anything but static; it derives its very life from being recreated time and again. Such an artwork obtains its identity only through the multitude of its successive performances. The equation of ecological restorations with artistic performances was made by Jordan in numerous writings (e.g., Jordan 1987). He denounces "environmentalism's blindness to the performative or expressive aspect of restoration - to what might be called its ritual value" (Jordan 2000: 215).

Moreover, the performing arts cannot thrive without an audience. Because artistic performances are public rituals, this version of the art restoration metaphor is akin to the community metaphor, which has a long tradition in ecology, especially in the land ethic of Aldo Leopold. According to Leopold's famous statement, "a land ethic changes the role of Homo sapiens from conqueror of the land community to plain member and citizen of it" (Leopold 1949: 240). Restorationists who have adopted the community metaphor perceive themselves as participants rather than as curators of museum pieces. Participation is supposed to strengthen the ties between humans and between the human community and the larger ecological community.

The analogy between ecological restoration and artistic recreation does more justice to the dynamic interplay of nature and culture that follows from our multifunctional use of natural resources than does the analogy between ecological restoration and the restoration of parts or pieces of a museum collection. In this respect, the metaphors of artistic recreation have some resemblance to metaphors from the domain of engineering and cybernetics - metaphors that are also human-inclusive rather than human-exclusive. They differ, however, with respect to the standard by which ecological restorations should be evaluated. In the first case, "authenticity" functions as a yardstick. An artistic performance should be true to the original score, script, or scenario. Although the players, the props, the scenery, and costumes constantly change, the performance has to remain Swan Lake. Unlike the above, metaphors from the domain of engineering and cybernet- 
ics are not about originality or authenticity but rather about "functionality." In this regard, these metaphors have more in common with a cluster of metaphors that have more recently emerged from the domain of medicine and health care.

\section{Medicine and Health Care}

Since about 1990, the notion of "health" has made an amazing career within environmentalism and ecology. Its domain of application has been extended from the level of the individual (clinical and veterinary medicine) and the population (epidemiology and public health) to the level of ecosystems. An interdisciplinary field of research has developed in which the relations between human activities, social organizations, natural systems, and health are being systematically explored. At present, the notion of health is a focal point for the integration of three highly overlapping areas of research activity: ecosystem medicine, geographical medicine, and conservation medicine.

"Ecosystem medicine" emerged in the early 1990s and gained momentum in 1994 with the establishment of the International Society for Ecosystem Health (ISEH). Since 1995, the ISEH has published the journal Ecosystem Health. The society is dedicated to the idea that a healthy ecosystem is one that provides services supportive of the human community, such as food, potable water, clean air, and the capacity for assimilating and recycling wastes. Ecosystem medicine aims at developing "a systemic approach to the preventive, diagnostic, and prognostic aspects of ecosystem management, and ... [at] understanding ... [the] relationships between ecosystem health and human health" (Rapport et al. 1999: 84). This approach is not entirely new. Aldo Leopold already refers to "the art of land doctoring" and "the science of land health."

Ecosystems are regarded as healthy as long as they have the capacity to maintain structure and function in the face of stress. Proponents of this approach talk about the "Ecosystem Distress Syndrome" (EDS). Some indicators of this syndrome are changes in primary productivity and in nutrient cycling, loss of species diversity, and return to early stages of succession.

The second area of research activity that uses a broad concept of health is "geographical medicine" or "geomedicine." Geographical medicine is a subdiscipline of epidemiology that studies the impact of the environment on the geographical distribution of health and ill- 
ness. There has recently been a growing concern about the influence on the health of human populations of global economic, technological, and environmental changes, including climate change, ozone depletion, loss of biodiversity, land degradation, desertification, deforestation, worldwide urbanization, and mass migration due to war or natural disasters. From 2000 to 2004, the journal Global Change and Human Health provided a platform for scientific research into the health impacts of these globalization processes (Martens et al. 2000).

The last area of research focusing on a broad health concept is called "conservation medicine." This new discipline combines techniques, facts, and concepts from public health, veterinary medicine, conservation biology, and plant pathology. Conservation medicine evolved out of a crisis: unprecedented levels of disease in many species as a result of the worldwide transformations of the host-parasite relations by climate change, chemical pollution, animal trade, encroachment into wildlife areas, and habitat fragmentation.

With the launch of the first issue of the journal EcoHealth in January 2004, the collaboration between these three areas of research activity took a more definite shape. This journal aims to build on the legacy of both Ecosystem Health and Global Change and Human Health and also intends to cover the area of conservation medicine that has not yet been represented by a scholarly journal.

In contrast to the art restoration metaphor, the health metaphor implies a "humans in" approach to ecosystem analysis and assessment. Consequently, the health metaphor is also less negative about technology than the art restoration metaphor: health does not depend on some original or authentic condition because people can feel healthy and function normally with a hearing aid, bypass, or artificial kidney. Given these differences, "rehabilitation" seems to provide a far more appropriate term for the health-centred approach than "restoration." Exponents of the "rehabilitation" approach share its human-inclusive and functionalist perspective with environmental engineers and ecotechnologists.

The health metaphor is an extremely powerful discursive tool. It is broad enough to encompass a variety of scientific approaches and, like the cybernetic concept of ecosystems, is compatible with mechanic and organic worldviews. It not only facilitates the cooperation between natural, social, and medical scientists but also has an important communicative function for the general public as well. It provides a vocabulary of symptoms, syndromes, diagnostic indicators, and so on with which laypeople are already familiar as potential or actual patients and consumers of health care services (Rapport et al. 1998). Over the last 
few years, the health metaphor has gained ground in ecological restoration. As Harris and Hobbs have noticed, the two emergent fields of ecosystem health and ecological restoration have the potential to complement one another comfortably: "If we view the concept of ecosystem health as the diagnostic toolbox and ecological restoration as the treatment toolbox for the management of damaged ecosystems, there is clearly the potential for useful synergy" (Harris and Hobbs 2001: 200).

The incorporation of the health metaphor into restoration ecology has recently provoked criticism from Mark Davis and Lawrence Slobodkin. They reject the idea that communities and ecosystems possess traits such as "health" and "integrity" because this idea is reminiscent of outdated ecological ideas of communities and ecosystems as integrated entities, like Clements's concept of plant communities as superorganisms. They argue that "attributes such as 'health' and 'integrity' can [only] be meaningfully applied to entities that have been directly shaped by evolution, such as individual organisms ... However, communities and ecosystems are not shaped as entities by evolution" (Davis and Slobodkin 2004: 1).

Davis and Slobodkin's argument is problematic because it does not appreciate that the use of metaphors is inevitable and, what is more, that metaphors fulfill indispensable cognitive functions. It is precisely the very inability to provide a "literal" transcription of a metaphor in a scientific theory that constitutes its heuristic power. The other side of the coin is, of course, that metaphors can only claim a limited validity. The potential advantages of the health metaphor should not seduce us to embrace it as the one and only truth. Like all metaphors, the health metaphor also falls short in some respects. Ecosystems will not, for example, visit a doctor with their complaints. They cannot announce that they are sick and then tell when they are feeling better. Moreover, in the case of ecosystems, there is more possibility of a conflict between the health of the whole and the health of the components than in the case of human organisms. (Hammond and Holland 1995: 285).

\section{Geography}

In his 2004 book Conserving Words, Daniel Philippon explores how the American environmental movement has been shaped by the seminal works of five famous nature writers. Each of these writers understood "nature" through a particular metaphor that enabled certain narratives that explained how human beings should interact with nature: fron- 
tier (Theodore Roosevelt), garden (Mabel Osgood Wright), park (John Muir), wilderness (Aldo Leopold), and utopia (Edward Abbey). Philippon calls these metaphors geographical metaphors because each of them refers to nature in terms of a particular place. He concludes his book with a discussion of what he considers to be the latest and most promising geographic metaphor: the metaphor of nature as an island. In fact, the island metaphor goes back to the New Ecology and to the work of Evelyn Hutchinson, in particular. In a pioneering article published in 1946, "Circular Causal Systems in Ecology," Hutchinson distinguishes two closely related approaches: the "biogeochemical" and the "biodemographic" approach.

Seen from a biogeochemical perspective, the entire biosphere appears as a giant cyclical system of energy, matter, and information that is able to maintain a dynamic equilibrium thanks to a series of feedback mechanisms. This perspective was elaborated on, in particular, by Hutchinson's student Howard Odum and his brother Eugene (see the first section on "Engineering and Cybernetics").

The biodemographic approach, on the other hand, deals with groups or communities of organisms, the so-called populations. In conformity with the cybernetic principle shared by both approaches, these populations are also perceived as systems attempting to maintain their stability under ever-changing conditions by means of feedback mechanisms. This approach was further elaborated on by Robert MacArthur, another of Hutchinson's students. In the 1960s, MacArthur, in collaboration with Edward Wilson, developed the "island theory," a theory on the biogeography of islands. The theory predicts the number of species on a given island, using the size of the island and the distance to the mainland as its main parameters. MacArthur and Wilson also assumed a dynamic equilibrium: although the taxonomic composition on the island is subject to continuous change, the number of species, which is determined by the rates of extinction and colonization, remains constant. Their 1967 book The Theory of Island Biogeography is one of the most frequently cited books in ecology and popular biology.

Although MacArthur and Wilson's theory and Odum's systems theory come from the same theoretical background, they differ widely in their rhetorical potential. Whereas the metaphor of nature as clockwork reinforces our confidence in our ability to repair damaged ecosystems like we repair "the radio or the family car," as Hutchinson once put it (Kwa 1987: 427), the metaphor of nature as an island reminds us that there are "limits to growth" and that nature cannot be 
endlessly exploited. It calls attention to the ongoing fragmentation and ecological isolation by the encroachment of civilization and all the risks of extinction that come with it.

As Philippon has noted, the island metaphor is intimately related to another metaphor, the network metaphor, which connotes connectivity through, for example, corridors, ecoducts, stepping stones, and coastal linkages. "Islands provide a means to discuss webs and networks and systems of influence" (Philippon 2004: 270).

While Odum's systems theory was very popular in the 1960s and 1970s, the island theory has had a lightning career from the early 1980s onward, especially within European nature policy. It has been used to underpin the network-notion, in the (metaphorical) sense that nature areas should be perceived as "islands in a sea of cultivated land." The theory also serves as a basis for the attempt to maximize the size of contiguous nature areas and the number of links between them.

The concept of a comprehensive network of nature areas was introduced in Europe with the 1992 directive on the conservation of natural habitats and of wild fauna and flora (the Habitats Directive). Together with the 1979 Birds Directive, the Habitats Directive constitutes the instrument for creating a European ecological network, the so-called Natura 2000, which is considered to be the cornerstone for the protection of biodiversity in Europe. Currently, the network concept is rapidly gaining more importance due to the growing need for migration of many species struggling to escape extinction as a result of climate change and of global change in general. ${ }^{2}$

Although the network metaphor is no more true or accurate than any of the other metaphors, it may well turn out to be more useful as a communicative device in scientific discourse, public debate, and political decision making about restoring nature. The network metaphor does not only connect areas, populations, and habitats, but it also encourages the creation and establishment of linkages between people, disciplines, and practices. It also enables communication and cooperation between environmentalists and ecologists over the whole restoration spectrum, from the islands and fragments of biodiversity and the corridors between them to the buffer zones and the wider surroundings.

\section{Toward a Multiple Vision}

As we have seen in the previous sections, every metaphor is restricted in range and relevance. Metaphors are like searchlights that highlight 
certain features while blocking out others. According to Lakoff and Johnson (1980: 165), each metaphor is true for certain purposes, in certain respects, and in certain contexts. As Sara Ebenreck has written, "Rather than proceed as if any one metaphor is the finally correct metaphor, ethicists conscious of the constructive imagination at work in these basic metaphors might be more aware of the limits of any metaphorical construction and more open to the experiences and values embodied in alternate metaphoric constructions of the Earth" (1996: 14). Moreover, the search for the one best metaphor is not without pitfalls and can lead to what Mark Meisner (1995: 14) has called "a sort of perceptual hegemony." This is the case if a metaphor ceases to be perceived as metaphor and is taken literally, so that we are no longer able to recognize that it represents but a singular perspective (see Slobodkin 2001).

In order to prevent such one-sidedness, we should adopt what Donald Schön and Martin Rein used to call a "double vision": "the ability to act from a frame while cultivating awareness of alternative frames" (Schön and Rein 1994: 207). We should learn to "squint," so to speak, in order to see things from different angles simultaneously, or we should develop what philosopher of technology Don Idhe (1993) has called a "compound eye."

Fostering a double-or multiple-vision is a necessary condition to solve conflicts that arise because opponents frame the problem at hand differently. However, often this kind of "frame reflection" will not be sufficient but also requires what Schön (1979) calls "frame restructuring." Hereby "we respond to frame conflict by constructing a new problem-setting story, one in which we attempt to integrate conflicting frames by including features and relations drawn from earlier stories" (Schön 1979: 270).

The ideal of pluralism, underlying the idea of a multiple vision on metaphor, should be distinguished from sheer relativism. Questions of judgment cannot be suspended, unless we assume that all metaphors are equally valid. How can this "relativist trap" be avoided? Is it possible to find criteria that allow us to distinguish better metaphors from lesser ones? This question is central to the controversy over the use of metaphors in invasion biology. Recently, the way non-native species have been conceptualized as "exotic," "alien," and "invaders" to be eradicated and exterminated has been criticized as overly militaristic, nationalist, and xenophobic. (Chew and Laubichler 2003; Gobster 2005; Larson 2005; O'Brien 2006; Simberloff 2003). I have discussed the implications of bellicose metaphors in ecology and nature conservation in another article (Keulartz and Van der Weele 2007 submitted). 
In this article, I want to answer the question of what the outcome would be of employing a multiple vision on ecological restoration. Given the similarities and differences between metaphors from cybernetics, aesthetics, medicine, and geography, how should we judge the value and meaning of these metaphors? And how do they relate to one another?

Environmental philosopher Baird Callicott and his colleagues Larry Crowder and Karen Mumford have provided us with an interesting possibility to arrange the most important metaphors used in restoring nature (Callicott et al. 1999). They distinguish two contemporary schools of conservation philosophy: "compositionalism" and "functionalism." According to Callicott and colleagues, the compositionalist emphasis is on the process of returning a biotic community to its original condition of biological diversity and integrity; whereas the functionalist emphasis is more on the process of returning an ecosystem to a state of health. Callicott and colleagues consider compositionalism and functionalism as two ends of a continuum: the compositionalist emphasis on the ecological restoration of biological integrity and diversity is appropriate for the management of the less severely degraded areas such as wilderness areas, national parks, and state parks. The functionalist emphasis on the ecological rehabilitation of ecosystem health is more suited for the much greater part of the world that is inhabited and economically exploited by humans.

Using the island metaphor, Callicott cum suis argue that the compositionalist and functionalist approaches have a complementary and dialectical relationship. "The preservation of islands of biological diversity and integrity and ecological restoration necessarily occurs at present in a humanly inhabited and economically exploited matrix. Hence the success of nature preservation and restoration necessarily depends on ecologically rehabilitating and maintaining the health of these matrices. On the other hand the maintenance of ecosystem health in humanly inhabited and economically exploited areas depends upon the existence of reservoirs of biological diversity and integrity" (Callicott et al. 1999: 32).

With the notion of a spectrum of conservation philosophies and nature management styles between the poles of less and more severely degraded areas, the above quote suggests an answer to our question with respect to a multiple vision on ecological restoration. This notion should, however, be expanded to include environmental engineering and ecological engineering (or ecotechnology) as well. After all, metaphors from the domain of engineering and cybernetics share a marked 


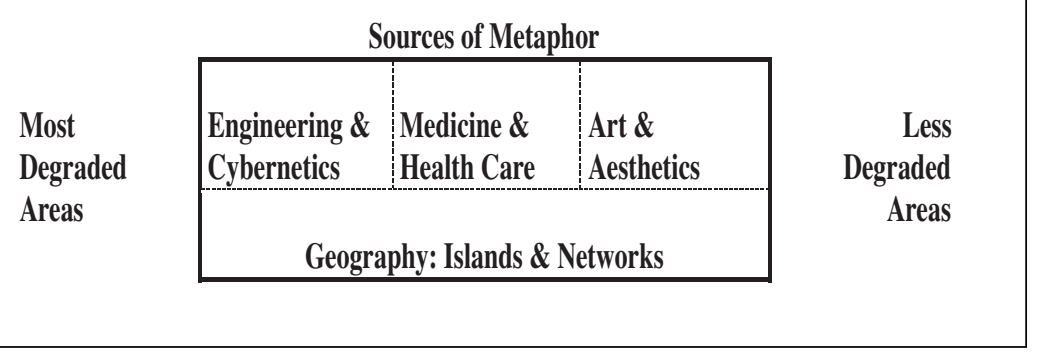

Figure 1 - Sources of Metaphors on a Scale from Most to Less Degraded Areas

functionalism with metaphors from the domain of medicine and health care, in apparent contrast to metaphors from the field of art and aesthetics, which have an obvious compositionalist emphasis (Figure 1). ${ }^{3}$

Note that the way the domain of geography is presented differs from the way the other domains are represented in the figure. This is because the island metaphor (and the associated network metaphor) is underlying the continuum of Callicott cum suis. We will come back to this aspect of the figure in our discussion.

\section{Discussion}

The notion of a spectrum ranging from less to most severely degraded areas can be useful in addressing potential problems of communication, coordination, and cooperation between various scientific (sub)disciplines, management practices, and the general public. On the other hand, this notion is also problematic because in many cases there is simply no agreement on what should count as degraded or not. Take the Chicago Restoration Controversy, which broke out as soon as plans to clear forestland to create prairies and open woodlands were made public. The restoration stewards, who considered the actual landscape as "degraded" and "overgrown," invited their critics to visit some of their preserves in the hope of winning them over. However, this was unsuccessful. Whereas the restoration stewards valued the recently burned woodlands as beautiful sites, "finally opened up so that the native understory could return," the critics saw the scorched woodlands as "virtually wastelands where the soil is sterile and nothing but charred stumps remain." For one group it was an exciting and promising site; for the 
other it was a sad and scary portent of the future of the land (Helford 2000: 130).

One possible explanation for the intractability of the Chicago Restoration Controversy is the use of metaphors of invasion and war by the restoration volunteers. On the one hand, the martial view of restoration work had a positive effect on reinforcing the volunteers' commitment and willingness to sacrifice for their case. On the other hand, this view may have intensified the controversy. For volunteers who saw themselves as combatants in a war to save nature, it was easy to view their opponents as enemies of nature. "The immediate impulse was to fight and try to defeat these enemies, rather than to try to understand their objections and look for ways to negotiate and compromise" (Schroeder 2000: 262).

It is clear from this and many other controversies that what people consider as degraded areas depends on their perceptions of nature and, in particular, on the metaphors they use to express their attitude towards nature. As we saw in the previous section, Callicott and colleagues also specify their notion of degradation with the help of a metaphor, namely, the metaphor of nature areas as islands that are in increasing danger of being engulfed by the sea of cultivated land. It is exactly because the island metaphor is underlying the continuum of Callicott cum suis that the domain of geography is represented differently than from the other metaphors in Figure 1.

At this point we run the risk of going in a circle: the plausibility of the classification of metaphors according to the kind of site (more or less severely degraded) seems to depend on the plausibility of yet another metaphor. This suggests that it is impossible to break out of the circle of metaphors and to find criteria to evaluate metaphors outside or beyond this circle. But-and this is the first step to a solution of the problem - this circle should not be seen as a vicious circle that one should try to break out of, but should instead be considered a hermeneutic circle of part and whole, of text and context, that we should try to enter in the right way.

The force of metaphors depends on the whole system or "ecology" of metaphors that together constitute the cultural context, the cultural climate in a particular era. Whether metaphors can acquire significant cognitive, discursive, or normative power is determined by the degree to which they resonate with social values and visions that are dominant in a certain period. As we have seen at some length in section 4, the island metaphor and the adjacent network metaphor currently seem to have the best credentials among professionals and within the larger pub- 
lic as well. Given this "working consensus," I think that my proposal to arrange the different metaphors based on Callicott's notion of a spectrum from less to most severely degraded areas seems sufficiently justified.

Of course, this proposal cannot claim absolute validity but is contextspecific and relative with respect to time, place, and circumstance. We should stay aware of our hermeneutic situation, but, on the other hand, we should also proceed pragmatically and prevent reflexivity from degenerating into hyper-reflexivity. As Ludwig Wittgenstein so eloquently argued in his collection On Certainty, "We just can't investigate everything, and for that reason we are forced to rest content with assumption. If I want the door to turn, the hinges must stay put" (Wittgenstein 1969-1975: proposition 343). ${ }^{4}$

\section{Conclusion}

In this article the most common metaphors for framing ecological restoration have been explored in some detail. Acknowledging the fact that every metaphor inescapably falls short in some respect, the article argues that the search for the one best metaphor is a dead end and claims that we should develop a multiple vision instead. An attempt has been made to create some order out of the chaos of different and often diverging metaphors. The proposal to arrange these metaphors according to a scale from less to most severely degraded areas, however incomplete or imperfect, could help improve communication and cooperation across the borders between people from different disciplines, between practitioners and theoreticians, and between experts and laypeople.

\section{Acknowledgments}

I would like to thank Matthias Gross, Jac. A. A. Swart, Cor van der Weele, Mike Weinstein, and Henny van der Windt for their useful comments on an earlier version of this article. This study was supported by the "Ethics and Policy" research program of the Netherlands Organisation for Scientific Research (NWO).

Jozef Keulartz is an associate professor in Applied Philosophy at Wageningen University and Research Centre. He has been appointed special chair for Environmental Philosophy at Radboud University Nijmegen. Keulartz is 
a member of the Scientific Council of the European Centre for Nature Conservation $(\mathrm{ECNC})$ and the Netherlands Commission on Genetic Modification (GOGEM). He is a member of the International Working Group on Sustainability, and also participates in ALTER-net, a "network of excellence," funded by the EU's 6th Framework Programme.

\section{Notes}

1. This list was obtained by examining the most relevant journals and some key publications. Note that "ecological restoration" is broadly defined because it is still a highly dynamic field and shows considerable overlap with other disciplines.

2. We may credit the Greenway Movement in the United States with having anticipated the idea of thinking in terms of green networks (Fabos and Ryan 2006). The movement started off in the mid 1860s when Frederick Law Olmsted and his colleagues began designing park systems in and around cities. These systems were composed of urban parks connected by parkways. After fading from public consciousness during the second third of the previous century, the greenway concept enjoyed a popular revival in the early 1970s, with clear recognition of the ecological importance of the green connections and environmental corridors.

3. To prevent any misunderstandings, it should be stressed that the idea of a continuum is conflicting with the notion of clear-cut borderlines between the various areas and is only compatible with gradual differences, allowing for all kinds of mixed territories, and, by implication, by all sorts of combinations of models and metaphors.

4. What should be considered a hinge depends on the problem under investigation. It can be argued that the very idea of restoration ecology can be used as a hinge for ecological studies. William R. Jordan III takes this view when he regards the ability to reassemble a community or ecosystem and to make it function properly as a critical test of ecological understanding in the most fundamental sense (see e.g. Jordan et al. 1987: 6).

\section{References}

Bergson, Henri. 1907. L'Evolution Créatrice. Paris: Alcan.

Callicott, Baird, Larry Crowder, and Karin Mumford. 1999. "Current Normative Concepts in Conservation." Conservation Biology 13 (1): 22-35.

Chew, Matthew, and Manfred Laubichler. 2003. "Natural Enemies-Metaphor or Misconception?" Science 301: 52-53.

Davis, Mark, and Lawrence Slobodkin. 2004. "The Science and Values of Restoration Ecology." Restoration Ecology 12 (1): 1-3.

Ebenreck, Sara. 1996. "Opening Pandora's Box: Imagination's Role in Environmental Ethics." Environmental Ethics 18: 3-18.

Eliot, Robert. 2003. "Faking Nature." Pp. 381-389 in Environmental Ethics: An Anthology, eds. Andrew A. Light and Holmes Rolston. Cambridge: Blackwell Publishers.

Fabos, Julius, and Robert Ryan. 2006. "An Introduction to Greenway Planning around the World." Landscape and Urban Planning 76 (1): 1-6. 
Gobster, Paul. 2005. "Invasive Species as Ecological Threat: Is Restoration an Alternative to Fear-Based Resource Management?" Ecological Restoration 23 (4): 260-269.

Gobster, Paul, and Bruce Hull, eds. 2000. Restoring Nature. Washington, D.C.: Island Press.

Hammond, Micheal, and Alan Holland. 1995. "Ecosystem Health: Some Prognostications." Environmental Values 4: 283-286.

Harré, Rom, Jens Brockmeier, and Peter Mühlhäusler. 1999. Greenspeak: A Study of Environmental Discourse. London: Sage Publications.

Harris, James J., and Richard J. Hobbs. 2001. "Clinical Practice for Ecosystem Health: The Role of Ecological Restoration." Ecosystem Health 7 (4): 195-202.

Helford, Reid. 2000. "Constructing Nature as Constructing Science." Pp. 119-143 in Restoring Nature, eds. Paul Gobster and Bruce Hull. Washington, D.C.: Island Press.

Hellsten, lina. 2002. The Politics of Metaphor: Biotechnology and Biodiversity in the Media. Tampere: Tampere University Press:

Idhe, Don. 1993. Philosophy of Technology: An Introduction. New York: Paragon.

Jordan, William R., III. 1987. "Restoration and Management as Theatre." Restoration \& Management Notes 5 (1): 2.

Jordan, William R., III. 2000. "Sunflower Forest." Pp. 205-220 in Environmental Restoration: Ethics, Theory, and Practice, ed. William Throop. Amherst, N.Y.: Humanity Books.

Jordan, William R., III, Michael Gilpin, and John Aber, eds. 1987. Restoration Ecology: A Synthetic Approach to Ecological Research. Cambridge: Cambridge University Press.

Katz, Eric. 2003. "The Big Lie: Human Restoration of Nature." Pp. 390-397 in Environmental Ethics: An Anthology, eds. Andrew Light and Holmes Rolston. Cambridge: Blackwell Publishers.

Keulartz, Jozef. 1998. The Struggle for Nature: A Critique of Radical Ecology. London: Routledge.

Keulartz, Jozef, and Cor van der Weele. 2007. "How to Judge the Value of Metaphor? The Case of Invasive Species." Configurations (submitted).

Kwa, Chunglin. 1987. "Representation of Nature Mediating between Ecology and Science Policy: The Case of the International Biological Programme." Social Studies of Science 17 (3): 413-442.

Lakoff, George, and Mark Johnson. 1980. Metaphors We Live By. Chicago: University of Chicago Press.

Larson, Brendon. 2005. "The war of the roses: demilitarizing invasion biology". Front Ecol Environ 3 (9): 495-500.

Leopold, Aldo. 1949. A Sand County Almanac. New York: Oxford University Press.

Light, Andrew. 2003. "Faking Nature Revisited." In The Beauty Around Us: Environmental Aesthetics in the Scenic Landscape and Beyond, eds. D. Michelfelder and B. Wilcox. Albany, N.Y.: SUNY Press.

Martens, Pim, Tom McMichael, and Jonathan Patz. 2000. "Globalisation, Environmental Change and Health." Global Change \& Human Health 1 (1): 4-8.

McCutcheon, Steven, and William Mitsch. 1994. "Ecological and Environmental Engineering: Potential for Progress." Ecological Engineering 3: 107-109.

McCutcheon, Steven, and Thomas Walski. 1994. "Ecological Engineers: Friend or Foe?" Ecological Engineering 3: 109-112. 
Meisner, Mark. 1995. "Metaphors of Nature: Old Vinegar in New Bottles?" Trumpeter 12 (1): 11-18.

Merchant, Carolyn. 1980. The Death of Nature: Women, Ecology and the Scientific Revolution. New York: Harper and Row.

Mills, W. T. 1982. "Metaphorical Vision: Changes in Western Attitudes to the Environment." Annals of the Association of American Geographers 72: 237-253.

Mitsch, William. 1994. "Ecological Engineering: A Friend." Ecological Engineering 3: 112-115.

O'Brien, William. 2006. "Exotic Invasions, Nativism, and Ecological Restoration: On the Persistence of a Contentious Debate." Ethics, Place and Environment 9 (1): 63-77.

Pepper, Stephen. 1942. World Hypotheses: A Study in Evidence. Berkeley: University of California Press.

Philippon, Daniel. 2004. Conserving Words: How American Nature Writers Shaped the Environmental Movement. London: University of Georgia Press.

Rapport, David, P.R. Epstein, R. Levins, R. Costanza and C. Gaudetl. 1998. Ecosystem Health. Malden, Mass.: Blackwell Science.

Rapport, David, G. Böhm, D. Buckingham, J. Cairns, Jr., R. Costanza, J.R. Karr, H.A.M. de Kruijf, R.Levins, A.J. McMichael, N.O. Nielsen and W.G. Whitford. 1999. "Ecosystem Health: The Concept, the ISEH, and the Important Tasks Ahead." Ecosystem Health 5 (2): 82-90.

Rolston, Holmes. 2000. "Restoration." Pp. 127-132 in Environmental Restoration: Ethics, Theory, and Practice, ed. William Throop. Amherst, N.Y.: Humanity Books.

Sagoff, Mark. 1978. "On Restoring and Reproducing Art." The Journal of Philosophy 75 (9): 453-470.

Schön, Donald. 1979. "Generative Metaphor: A Perspective on Problem-Setting in Social Policy." Pp. 254-284 in Metaphor and Thought, ed. A. Ortony. Cambridge: Cambridge University Press.

Schön, Donald, and Martin Rein. 1994. Frame Reflection. New York: Basic Books.

Schroeder, Herbert. 2000. "The Restoration Experience: Volunteers' Motives, Values, and Concepts of Nature." Pp. 247-264 in Restoring Nature, eds. Paul Gobster and Bruce Hull. Washington, D.C.: Island Press.

Simberloff, Daniel. 2003. "Confronting Introduced Species: A Form of Xenophobia?" Biological Invasions 5 (3): 179-192.

Slobodkin, Lawrence. 2001. "The Good, the Bad and the Reified." Evolutionary Ecology Research 3: 1-13.

Society for Ecological Restoration Science and Policy Working Group, 2004. The SER International Primer on Ecological Restoration. http:/www.ser.org (accessed 2312-2007).

Taylor, Peter J. 1988. "Technocratic Optimism: H. T. Odum, and the Partial Transformation of Ecological Metaphors after World War II." Journal of the History of Biology 21 (2): 213-244.

Throop, William, ed. 2000. Environmental Restoration: Ethics, Theory, and Practice. Amherst, N.Y.: Humanity Books.

Whitehead, Alfred. 1925. Science and the Modern World. New York: Macmillan.

Wittgenstein, Ludwig. 1969-1975. On Certainty (Über Gewissheit). Eds. Elizabeth Anscombe and George Henrik von Wright. Oxford: Basil Blackwell. http://budni.by .ru/oncertainty.html (accessed 23-12-2007).

Worster, Donald. 1977. Nature's Economy: A History of Ecological Ideas. Cambridge: Cambridge University Press. 